JOSÉ, D. P.; CAMPOS, J. M. S.; VICCINI, L. F.; ALKIMIM, E. R.; SANTOS, M. O. Micropropagation and ploidy stability of Lippia lacunosa Mart. \& Schauer: an endangered brazilian medicinal plant. Revista de Agricultura Neotropical, Cassilândia-MS, v. 6, n. 1, p. 1-7, jan./mar. 2019. ISSN 2358-6303.

\title{
Micropropagation and ploidy stability of Lippia lacunosa Mart. \& Schauer: an endangered brazilian medicinal plant
}

\author{
Diego Pandeló José ${ }^{1}$, José Marcello Salabert de Campos², Lyderson Facio Viccini², Emilly \\ Ruas Alkimim ${ }^{1}$, Marcelo de Oliveira Santos ${ }^{2}$ \\ ${ }^{1}$ Universidade Federal do Triângulo Mineiro, Campus Universitário de Iturama, Iturama, Minas Gerais, Brasil. E-mail: \\ diegopandelo@gmail.com, emillyalkimim@yahoo.com.br \\ ${ }^{2}$ Universidade Federal de Juiz de Fora, Departamento de Biologia, Juiz de Fora, Minas Gerais, Brasil. E-mail: joseufjf@ gmail.com, \\ lyderson.viccini@gmail.com, marcelo.santos@gmail.com
}

Received: 05/12/2018; Accepted: 28/01/2019.

\section{ABSTRACT}

Lippia lacunosa is a Brazilian savanna plant that belongs to the Verbenaceae family. It has been used in folk medicine as a treatment for different diseases. This species represents an endangered Brazilian medicinal plant, and this is the first report documenting a reliable protocol for the in vitro propagation and regeneration of L. lacunosa. Axenic explants were cultivated in MS medium containing different concentrations of naphthalene acetic acid (NAA) to induce root growth. The mean shoot length and the number of roots were highest with $0.06 \mathrm{mg} \cdot \mathrm{L}^{-1} \mathrm{NAA}$. The highest number of buds in shoot regeneration was induced with $2 \mathrm{mg} \cdot \mathrm{L}^{-1}$ 6-benzylaminopurine (BA). To obtain a long-term culture, the dwarf shoots were elongated on MS media containing $0.5 \mathrm{mg} \cdot \mathrm{L}^{-1} \mathrm{BA}$ alternated with MS containing $2 \mathrm{mg} \cdot \mathrm{L}^{-1} \mathrm{BA}$ every 40 days. In the present protocol, the long-term shoots retained the ability to root even after long periods of BA treatment. In addition, we evaluated the nuclear DNA content and ploidy levels, including the occurrence of endopolyploidy, in long-term micropropagated plant leaves using flow cytometry analysis. The plants propagated in vitro over several years possessed nuclear DNA contents ranging from 2.940 to $3.095 \mathrm{pg}$, and no differences in DNA content were found among in vitro plants or between these plants and the control (L. lacunosa from a greenhouse with a DNA content of $3.08 \mathrm{pg}$ ). The flow cytometry analysis also demonstrated that there was no polyploidization. The present study will be useful for biotechnological approaches and provides the first estimate of the nuclear DNA content of this species using flow cytometry.

Keywords: Brazilian savanna plant, In vitro propagation, Genomic stability, Flow cytometry, Disease treatment.

\section{Estabilidade de micropropagação e ploidia de Lippia lacunosa Mart. \& Schauer: uma planta medicinal brasileira ameaçada de extinção}

\section{RESUMO}

Lippia lacunosa é uma planta do Cerrado brasileiro pertencente à família Verbenaceae e utilizada na medicina popular como uma forma de tratamento para diferentes doenças. É uma espécie ameaçada de extinção e este é o primeiro relato mostrando um protocolo eficiente para a propagação e regeneração in vitro de L. lacunosa. Os explantes axênicos foram cultivados em meio MS contendo diferentes concentrações de ANA (ácido naftalenoacético) para indução de raízes. A média do comprimento das brotações e o número de raízes foram maiores quando expostos a $0,06 \mathrm{mg} . \mathrm{L}^{-1}$ de ANA. O maior número de gemas para regeneração de brotos foi induzido sob $2 \mathrm{mg} . \mathrm{L}^{-1}$ de BA (6-benzilaminopurina). Para obtenção de cultura a longo prazo, os brotos foram alongados em meio MS com BA 0,5 mg. $\mathrm{L}^{-1}$, alternando com MS contendo $2 \mathrm{mg} . \mathrm{L}^{-1}$ de BA a cada 40 dias. Os explantes mantiveram a capacidade de enraizar mesmo após longo período de tratamento com BA. Adicionalmente, foi analisado por citometria de fluxo o conteúdo de DNA nuclear e os níveis de ploidia, incluindo a ocorrência de endopoliploidia em folhas de plantas micropropagadas a longo prazo. Plantas micropropagadas durante anos apresentaram conteúdo de DNA nuclear variando de 2,940 a 3,095 pg, não sendo encontradas diferenças na quantidade de DNA em relação ao controle. A análise por citometria de fluxo também demonstrou que não houve indução de poliploidia. Os resultados obtidos podem ser utilizados para aplicações biotecnológicas e marcam o primeiro relato de quantificação do DNA nuclear desta espécie.

Palavras-chave: Planta do Cerrado brasileiro, Propagação in vitro, Estabilidade genômica, Citometria de fluxo, Tratamento de doenças. 


\section{Introduction}

The Lippia genus comprises nearly 200 taxa (Salimena and Múlgura, 2015) and 160 species distributed mainly in Brazil, Mexico, Central America, Africa, Paraguay, and Argentina, in addition to a few endemic African species (Sousa et al., 2012; Troncoso, 1974). Recently, some efforts have been made to characterize Brazilian Lippia species using genetic, cytogenetic, and propagation approaches (Peixoto et al., 2006; Viccini et al., 2004, 2005). These studies have helped us to understand the genetic organization and evolution of Lippia species, and to characterize the germplasm bank for biological, pharmacological, and agricultural research. Their pharmacological properties have been shown to be associated with their secondary metabolites, specifically their essential oils (Gomide et al., 2016; Pascual et al., 2001).

The great challenge of flora exploration is to find valuable resources for new drug, chemical, and pharmaceutical product development (Canter et al. 2005). Verbenaceae is one of the most important families present in Brazilian rupestrian fields due to their wide occurrence and the medicinal properties of some of the genera. The amount and quality of the essential oils, as well as their medicinal properties, place the genus Lippia in an outstanding position within the Verbenaceae family (Campos et al., 2011). The importance of this genus is further demonstrated by the occurrence of some endemic and endangered species (Vieira, 1999). The genus Lippia includes 88 species, of which 68 are endemic to Brazil (Salimena and Múlgura, 2015).

Gomide et al. (2016) evaluated the anti-proliferative effect of essential oils from four species of Lippia in CT26.WT colon tumor cells by measuring the cell cycle phase distribution and miRNA expression. CT26.WT cells showed cell cycle arrest in G2/M phase after specific treatment. Folk medicine uses Lippia lacunosa to treat colds and bacterial infections. Recently, an antimycobacterial activity of this plant was confirmed (Leitão et al., 2006). These species can be found only northeast of the Serra do Espinhaço (Minas Gerais state), organized in small populations varying from 10 to 40 individuals. The plant produces a lot of inflorescences, but few of them produce viable seeds, hindering the plant's natural propagation.

Tissue culture is a useful tool in plant species propagation and often constitutes the first step in biotechnological studies, especially for elite genotypes with sexual inbreeding difficulties. Thus, micropropagation is an important tool to optimize the production of rare plants with important biological activities and with propagation difficulties. Considering that tissue culture can be a source of genetic variation (Palomino et al., 1999; Jain, 2001), we propose a safe and stable protocol for L. lacunosa micropropagation. We used flow cytometry to estimate the genome size and to analyze the stability of the nuclear DNA content and ploidy levels in plant tissues propagated for long periods on BA (6-benzylaminopurine). We propose that flow cytometry can be adopted as a standard procedure for the evaluation of somaclonal variation in this genus. This is the first report showing a reliable protocol for the in vitro propagation and regeneration of L. lacunosa.

\section{Material and Methods}

Representative individuals from populations collected in the Serra do Espinhaço were sent to The Botanical Experimental Station at the Federal University of Juiz de Fora, Minas Gerais, Brazil, where they were cultivated. The voucher specimens were identified by the researcher Fátima Salimena, registered at Herbário CESJ (UFJF) with the number 41,691.

Young shoots from a single genotype up to $2 \mathrm{~cm}$ long and without leaves were rinsed for 30 seconds with ethanol (70 \% v/v), surface sterilized with sodium hypochlorite $(0.4 \% \mathrm{w} / \mathrm{v})$ solution for 15 minutes with agitation, and rinsed six times with sterile water. The shoots were cultivated in test tubes containing MS media (Murashige and Skoog, 1962) supplemented with $30 \mathrm{~g} \cdot \mathrm{L}^{-1}$ sucrose. The $\mathrm{pH}$ of the medium was adjusted to 5.7 before adding $6 \mathrm{~g} \cdot \mathrm{L}^{-1}$ agar and was autoclaved at $120^{\circ} \mathrm{C}$ and 1.1 atm for $15 \mathrm{~min}$. Cultures were maintained in $16 / 8 \mathrm{~h}$ (light/dark) regime, with 36 $\mu \mathrm{mol} \cdot \mathrm{m}^{-2} \cdot \mathrm{s}^{-1}$ light radiation provided by two fluorescent tubes at $26 \pm 2{ }^{\circ} \mathrm{C}$. The percentage of successful explants was evaluated after one week. Shoots from nodal segments introduced in vitro were subcultivated in the same medium described above every 14 days and used in the subsequent experiments.

Multiple shoots were induced using MS medium supplemented with BA $\left(0 \mathrm{mg} \cdot \mathrm{L}^{-1}, 0.5 \mathrm{mg} \cdot \mathrm{L}^{-1}, 1 \mathrm{mg} \cdot \mathrm{L}^{-1}\right.$, or $\left.2 \mathrm{mg} \cdot \mathrm{L}^{-1}\right)$. Nodal segments $1 \mathrm{~cm}$ long were placed horizontally on medium containing a single node and each of them was cultivated in a jar containing $40 \mathrm{~mL}$ shooting media. After 40 days, the number of shoots and the average length of the elongated shoots (longer than $2 \mathrm{~cm}$ ) were evaluated. The experiment consisted of a random design containing four repetitions of 15 explants each. The shoots obtained from the clusters cultured with MS supplemented with BA (2 mg. $\mathrm{L}^{-1}$ and $\left.1 \mathrm{mg} \cdot \mathrm{L}^{-1}\right)$ were then elongated on MS medium without BA for a period of 40 days in jars. Additionally, the cluster obtained from culture with $2 \mathrm{mg} \cdot \mathrm{L}^{-1} \mathrm{BA}$ was cut into small fragments and cultivated in different MS BA treatments $\left(0 \mathrm{mg} \cdot \mathrm{L}^{-1}, 0.5 \mathrm{mg} \cdot \mathrm{L}^{-1}, 1 \mathrm{mg} \cdot \mathrm{L}^{-1}\right.$, or $\left.2 \mathrm{mg} \cdot \mathrm{L}^{-1}\right)$ to induce de novo organogenesis.

For rooting evaluation, shoot tips $2 \mathrm{~cm}$ long containing two nodal segments were subcultivated in 
the same medium (described above) with different NAA (naphthalene acetic acid) concentrations $\left(0 \mathrm{mg} \cdot \mathrm{L}^{-1}, 0.02\right.$ $\mathrm{mg} \cdot \mathrm{L}^{-1}, 0.04 \mathrm{mg} \cdot \mathrm{L}^{-1}, 0.06 \mathrm{mg} \cdot \mathrm{L}^{-1}, 0.08 \mathrm{mg} \cdot \mathrm{L}^{-1}$, or 0.1 $\left.\mathrm{mg} \cdot \mathrm{L}^{-1}\right)$. All explants were incubated in a growing room at $25 \pm 2^{\circ} \mathrm{C}$ for a $16 \mathrm{~h}$ photoperiod and with a photon flux density of $35 \mathrm{mmol} \cdot \mathrm{m}^{2} \cdot \mathrm{s}^{-1}$ provided by cool-white fluorescent tubes. The treatments were arranged in a completely random design with four repetitions. The mean number of roots was calculated from 12 explants evaluated after 45 days. A total of 112 rooted plants were transferred to plastic vessels containing $50 \mathrm{~mL}$ of substrate (Plantmax ${ }^{\mathrm{TM}}$, Eucatex, São Paulo, Brazil) and covered with a plastic bag for four weeks in a growing room with $100 \%$ humidity. The plants were then cultivated in air with 50-70\% humidity and the number of surviving plants was evaluated after two months. The surviving plants were transferred into $500 \mathrm{~mL}$ plastic bags containing a mixture of soil and sand (3:1) and were cultivated in a green house. This process was repeated twice.

To evaluate genomic stability, we used fresh leaves from 30 elongated shoots from independent clusters obtained from long-term cultures (five year old in vitro plants cultivated with alternating treatments for the induction of multiple shoots and elongation as described above). The shoots were elongated with the addition of BA $\left(0.5 \mathrm{mg} \cdot \mathrm{L}^{-1}\right)$ and rooted in MS medium supplemented with NAA $\left(0.06 \mathrm{mg} \cdot \mathrm{L}^{-1}\right)$ to evaluate their genomic stability using flow cytometry. For DNA content determination, approximately $20-30 \mathrm{mg}$ of fresh leaf and the same weight of Pisum sativum fresh leaf (internal reference standard) were chopped up with a razor blade in $1 \mathrm{~mL} \mathrm{LB01}$ ice buffer to release the nuclei (Dolezel et al., 1997). The chopped tissue was aspirated through two layers of cheesecloth with a plastic pipette, filtered through a $50 \mu \mathrm{m}$ nylon filter, and collected in a polystyrene tube. The nuclei suspensions were stained with $25 \mu \mathrm{L}$ of $1 \%$ propidium iodide (w/v) and $5 \mu \mathrm{L}$ of RNase $\left(20 \mathrm{mg} \cdot \mathrm{L}^{-1}\right)$ was added to each sample. The samples were stored in a dark refrigerator and analyzed after 1 to $2 \mathrm{~h}$. At least 10,000 nuclei were analyzed for each sample using a logarithmic scale display. The analysis was performed with a FacsCalibur cytometer (Becton Dickinson). Each flow cytometric histogram was saved using Cell Quest software and analyzed using WinMDI 2.8 software (available at http://facs.scripps.edu/software.html).

The nuclear DNA content in picograms (pg) of each species was estimated as follows:

Sample, 2 CDNA $=\frac{\text { Peakchannelof species }}{\text { Peakchannelof } P \text {. sativum }} 2$ CDNAcontentofstandard $(9.09 \mathrm{pg})$

To determine the best treatment for explant rooting and shooting the data were evaluated using an analysis of variance (ANOVA) followed by a Tukey test $(p<0.05)$. For the assessment of genomic stability, two leaves from each of the 30 samples were analyzed. The leaves of L. lacunosa maintained in a greenhouse were used as a control. Analysis of variance (ANOVA) was employed to analyze the variation in DNA content among individuals and between them and the control.

\section{Results and Discussion}

The level of explant contamination was high, at $70.6 \%$. The mother shoots started browning, and newly axenic shoots emerged 20 days after commencement of the culture. These shoots were transferred into treatments to induce the production of multiple shoots for use in subsequent experiments. Treatment with different concentrations of BA induced the production of different numbers of shoots (Figure 1A). Treatment with BA $\left(2 \mathrm{mg} \cdot \mathrm{L}^{-1}\right)$ produced the highest number of shoots, 43.83 per cluster. The treatments containing MS supplemented with 0 or $0.5 \mathrm{mg} \cdot \mathrm{L}^{-1}$ BA produced elongated shoots (Figure 2A), whereas the treatments with 1 and $2 \mathrm{mg} \cdot \mathrm{L}^{-1}$ BA produced severely dwarfed shoots (Figure 2B). After 40 days of culture, all shoots treated with $\mathrm{MS}$ with $0 \mathrm{mg} \cdot \mathrm{L}^{-1}$ or $\mathrm{MS}$ with BA 0.5 $\mathrm{mg} \cdot \mathrm{L}^{-1}$ had elongated (Figure 2C). The clusters produced by treatment with MS with $2 \mathrm{mg} \cdot \mathrm{L}^{-1} \mathrm{BA}$ were cut into small fragments $\left(0.25 \mathrm{~cm}^{2}\right)$ and transferred into different BA treatments to produce elongated shoots (Figure 1B) by de novo organogenesis (Figure 2D).

The axenic explants were cultivated on MS medium containing different concentrations of NAA to induce rooting. The highest average number of roots $(8.48$ per shoot) and the highest average length of shoots (8.96 $\mathrm{cm}$ ) both occurred at $0.06 \mathrm{mg} \cdot \mathrm{L}^{-1} \mathrm{NAA}$ (Figures $1 \mathrm{C}$ and $1 \mathrm{D}$, respectively). Plants without roots that were transferred to soil died, however, $91.2 \%$ of plants that acclimatized after rooting survived (data not shown).

To estimate the nuclear genome size, the relative fluorescence intensity of PI stained nuclei isolated from L. lacunosa and P. sativum was compared. Distinct G1 (coefficient of variation $[\mathrm{CV}]=3.57$ ) and $\mathrm{G} 2 / \mathrm{M}$ peaks for L. lacunosa and a G1 peak for P. sativum $(\mathrm{CV}=2.98)$ were observed (Figure 3 ). The plants maintained in vitro long-term possessed nuclear DNA contents ranging from 2.940 to $3.095 \mathrm{pg}$. No statistical differences in DNA content were found among the in vitro plants or between these plants and the control (L. lacunosa from a greenhouse with a DNA content of $3.08 \pm 0.0134$ ).

The CV values obtained (Table 1) were lower than five, which is generally considered acceptable (Galbraith et al., 2001; Dolezel et al., 2007). In all histograms, only $2 \mathrm{C}$ and 4C peaks were detected for $L$. lacunosa (Figure 3). These results indicate that micropropagation of L. lacunosa under the conditions described did not introduce abnormalities such as mixoploidy or polyploidy. 

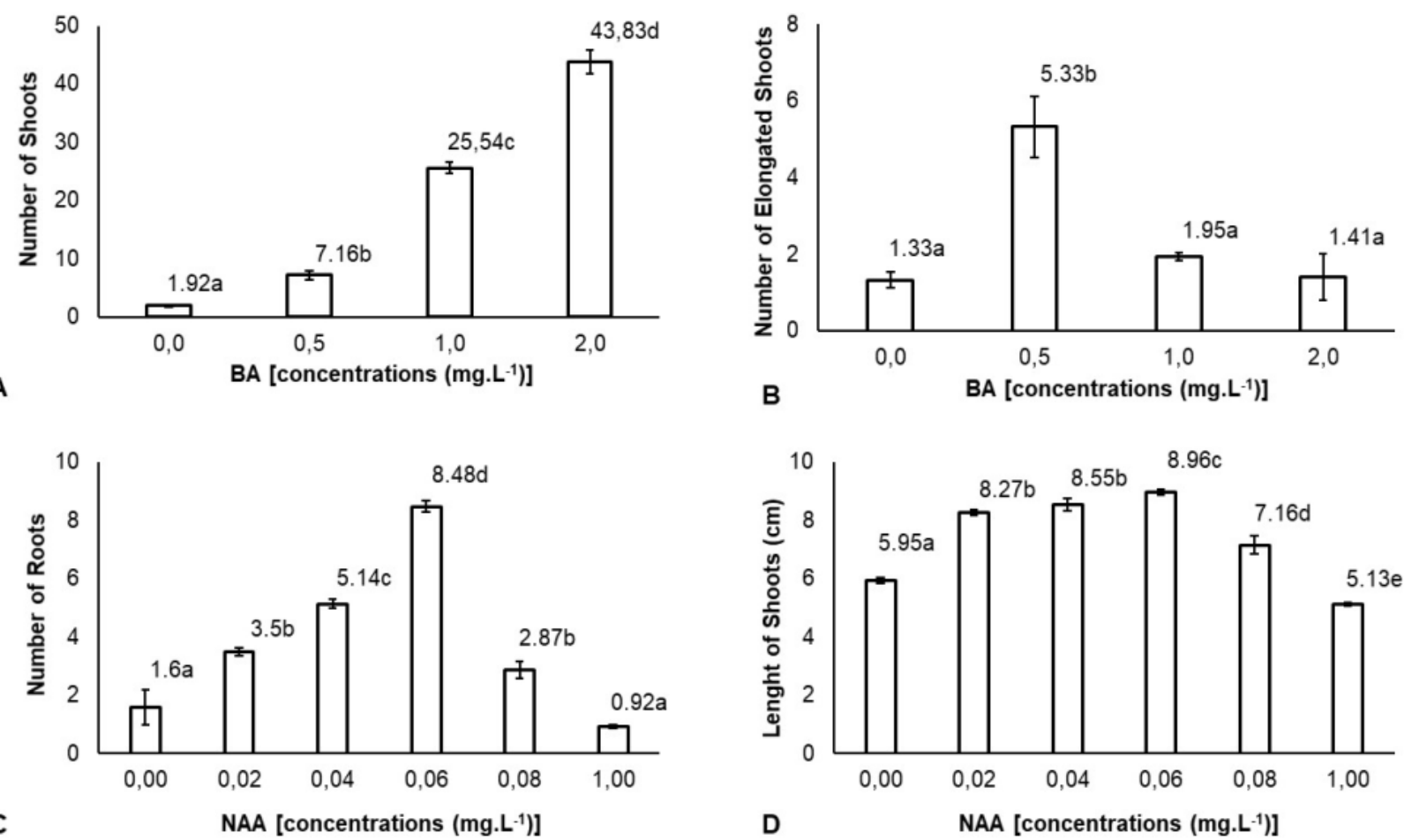

Figure 1. Number of roots (A) and length of shoots $(\mathrm{cm})(\mathrm{B})$ in different BA concentrations. Number of shoots $(\mathrm{C})$ and number of elongated shoots (D) in different NAA concentrations. Bars with the same letter are not statistically different $(p<0.05)$. The means are shown to the right of each bar.
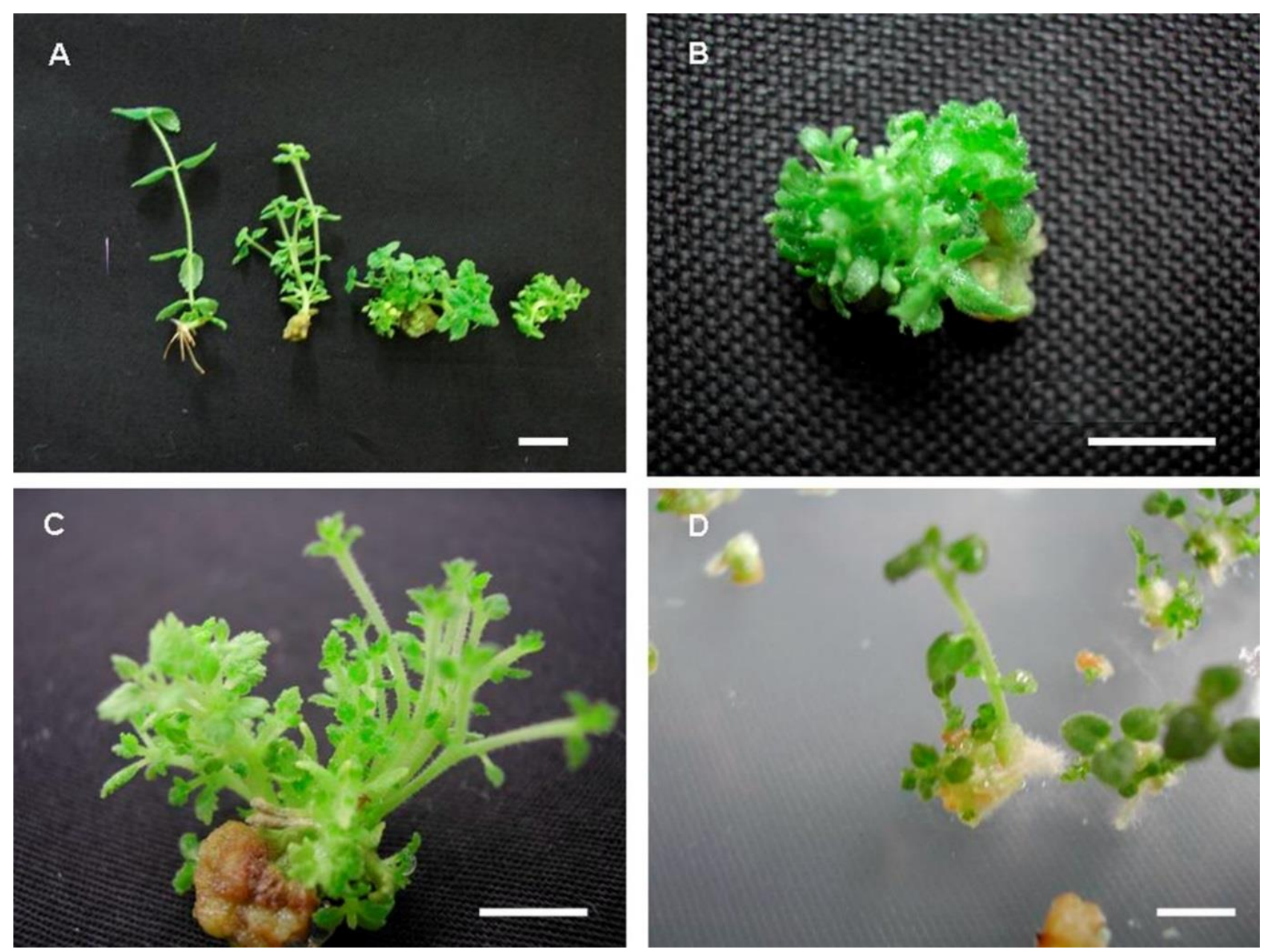

Figure 2. A) Shoots induced with BA $\left(0,0.5,1\right.$, and $\left.2 \mathrm{mg} \cdot \mathrm{L}^{-1}\right)$; B) Callus induced with $2 \mathrm{mg} \cdot \mathrm{L}^{-1} \mathrm{BA}$; C) Shoots elongated long-term with $0.5 \mathrm{mg} \cdot \mathrm{L}^{-1} \mathrm{BA}$; D) Regeneration of shoots from a sliced callus (bars $=1 \mathrm{~cm}$ ). 


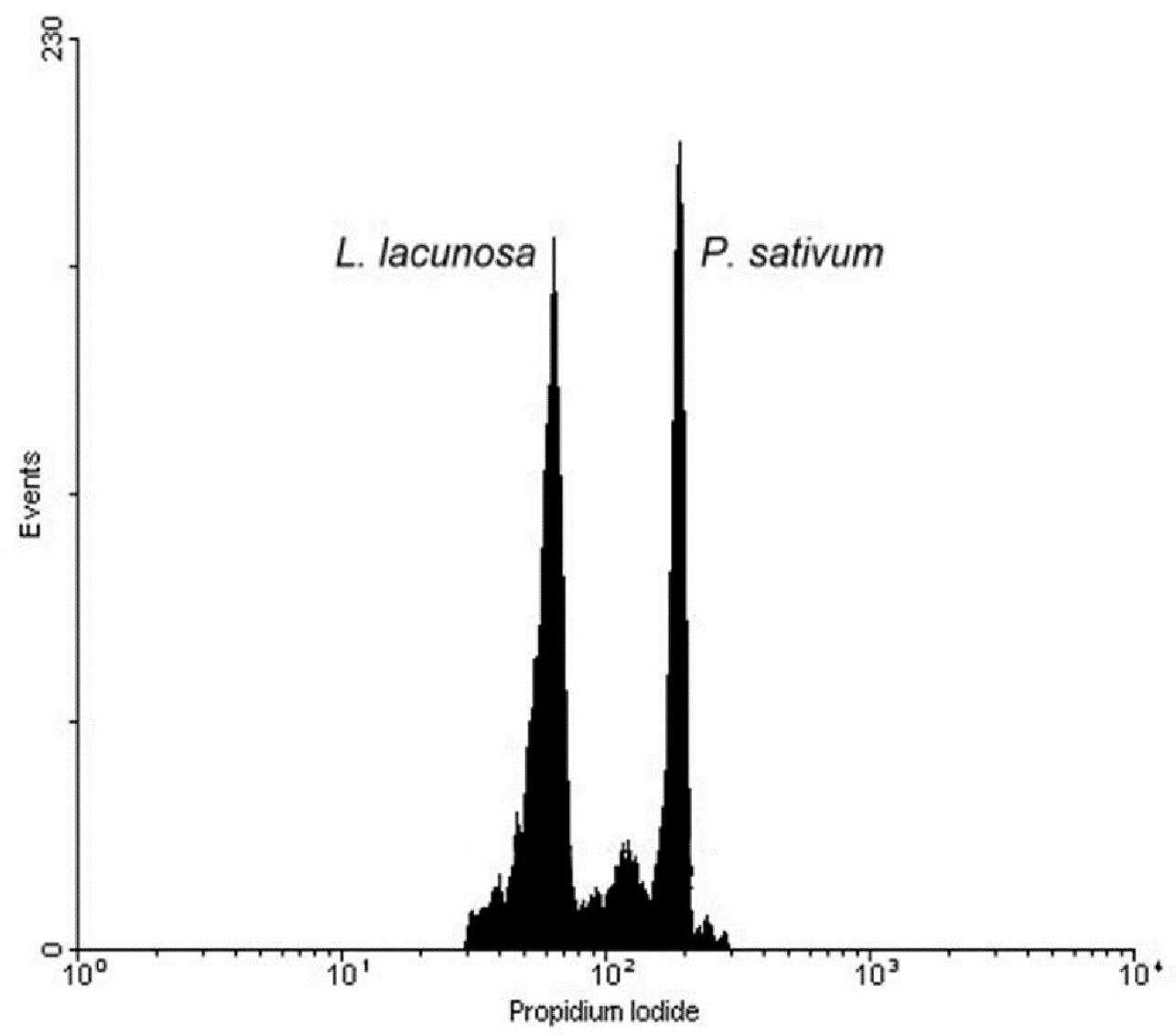

Figure 3. Histogram of DNA content estimation for L. lacunosa in relation to P. sativum (internal reference standard). Note the presence of only $2 \mathrm{C}$ and $4 \mathrm{C}$ cells for L. lacunosa.

Table 1. Nuclear DNA content of micropropagated plantlets and control (greenhouse L. lacunosa) Mean nuclear DNA content \pm SD and coefficient of variation $(\mathrm{CV})($ Mean $\pm \mathrm{SD})$ are shown.

\begin{tabular}{ccc}
\hline Plants & Nuclear DNA content (pg/2C) & CV $(\%)$ \\
\hline Plantlets (individuals) & $3.019 \pm 0.089$ & $4.36 \pm 0.1231$ \\
\hline Control (greenhouse L. lacunosa) & $3.080 \pm 0.013$ & $3.43 \pm 0.0234$ \\
\hline
\end{tabular}

The in vitro propagation method proposed in the present work produced a high percentage of stable elongated shoots after long-term BA treatment. Although the explants showed a dwarf phenotype after subculture with a dosage of $2 \mathrm{mg} \cdot \mathrm{L}^{-1}$, transfer of the clusters to a new medium supplemented with a low concentration of BA $\left(0.5 \mathrm{mg} \cdot \mathrm{L}^{-1}\right)$ reversed this effect and allowed them to elongate. Additionally, the sliced cluster demonstrated de novo organogenesis, which is useful for plant transformation. These shoots showed an optimal rooting and elongation ability under auxin treatment with NAA $0.06 \mathrm{mg} \cdot \mathrm{L}^{-1}$, although long periods of exposition to BA generally reduced rooting ability. These results were different from those of Lippia filifolia, which showed a reduced rooting ability in MS supplemented with NAA (Peixoto et al., 2006).

Thus, the sequence of treatments proposed in the present study will be useful for producing L. lacunosa on a large scale, and provides a valuable method for inducing multiple shoots after additional subcultures for a long period without altering the ploidy level. The long-term cultures ( 5 years) had been maintained in cycles of 40 days of alternating BA $\left(2 \mathrm{mg} \cdot \mathrm{L}^{-1}\right)$ and BA $\left(0.5 \mathrm{mg} \cdot \mathrm{L}^{-1}\right)$. These results indicate that this is a safe method for the propagation of $L$. lacunosa. This is an important observation, since these plantlets could be used as a source of new individuals for natural population recovery. Ploidy variations are the most common causes of genetic instability in tissue cultures, often leading to loss of the regeneration capacity of the culture material (Phillips et al., 1994).

To ensure that the long-term culture of L. lacunosa did not lead to somaclonal variation, we evaluated the genetic stability using flow cytometry. This tool has been extensively used for the analysis of genome stability. Loureiro et al. (2007) used this technique to analyze the ploidy stability of Juniperus phoenicea. In this study, the flow cytometry screening for ploidy 
changes revealed no differences among plants or between them and the mother plant. The genetic stability of the medicinal plant Scutellaria baicalensis maintained in vitro has also been assessed by flow cytometry (Alan et al., 2007). No significant variation in the nuclear DNA content or ploidy levels were observed. In our report, the nuclear DNA content of in vitro propagated plants showed no difference compared to the control (greenhouse L. lacunosa). All analyses showed only $2 \mathrm{C}$ and $4 \mathrm{C}$ peaks containing an average of $85.23 \%$ and $14.77 \%$ of the analyzed nuclei, respectively. This pattern is considered normal for cells in an active cell cycle (Dolezel et al., 2007). Nuclei with $8 \mathrm{C}$ or other ploidy levels were not detected.

The importance of showing $\mathrm{CV}$ values in this kind of study was pointed out by Marie and Brown (1993), who suggested that $\mathrm{CV}$ values should be used as an elementary parameter criterion to ensure the precision of the obtained values. These authors also stated their reference guideline, a range of 1-2\% for top-quality analyses in plant cells, and around $3 \%$ as a routine value (Marie and Brown, 1993). On the other hand, Galbraith et al. (2001) defined a CV of less than $5 \%$ as acceptable.

Loureiro et al. (2007) reported CVs of $3.46 \%$ for plantlets maintained in vitro, and Alan et al. (2007) documented CVs ranging from $3.48 \%$ to $6.77 \%$. In our study, the mean CV was $4.36 \%$ for in vitro plants, which was similar to other reports. However, it is still important to note, despite the fact that polyploidization was not found during the in vitro culture of L. lacunosa, the CV values obtained could mask the possible occurrence of small differences in nuclear DNA content. Consequently, the presence of a low level of aneuploidy should not be excluded.

\section{Conclusions}

The flow cytometry analysis excluded the occurrence of alterations such as mixoploidy and polyploidy. The development of an efficient and stable plant micropropagation procedure, and the high level of genetic stability observed in L. lacunosa maintained in vitro, provide a variety of opportunities, such as enabling long-term aseptic propagation and easy distribution of well-characterized germplasm lines of this plant species.

\section{Bibliographic References}

Alan, A.R., Zeng, H., Assani, A., Shi, W.L., McRae, H.E., Murch, S.J., Saxena, P.K., 2007. Assessment of genetic stability of the germplasm lines of medicinal plant Scutellaria baicalensis Georgi (Huang-qin) in long-term, in vitro maintained cultures. Plant Cell Reports, 26, 1345-1355.
Campos, J.M.S., Sousa, S.M., Silva, P.S., Pinheiro, L.C., Sampaio, F., Viccini, L.F., 2011. Chromosome numbers and DNA $C$ values in the genus Lippia (Verbenaceae). Plant Systematics and Evolution, 291, 133-140.

Canter, P.H., Thomas, H., Ernst, E., 2005. Bringing medicinal plants into cultivation: opportunities and challenges for biotechnology. Trends in Biotechnology, 23, 180-185.

Dolezel, J., 1997. Application of flow cytometry for the study of plant genomes. Journal of Applied Genetics, 38, 285-302.

Dolezel, J., Greilhuber, J., Suda, J., 2007. Flow Cytometry with Plant Cells, first ed. Wiley-VCH Verlag GmbH \& Co. $\mathrm{KGaA}$, Weinheim.

Galbraith, D.W., Lambert, G.M., Macas, J., Dolezel, J., 2001. Analysis of Nuclear DNA Content and Ploidy in Higher Plants, in: Robinson, J.P., (Ed.), Current Protocols in Cytometry. John Wiley \& Sons, New York, pp 7.6.1-7.6.22.

Gomide, M., Lemos, F., Reis, D., José, G., Lopes, M., Machadoc, M.A., Alves, T., Coelho, C.M., 2016. Identification of dysregulated microRNA expression and their potential role in the antiproliferative effect of the essential oils from four different Lippia species against the CT26.WT colon tumor cell line. Revista Brasileira de Farmacognosia, 26, 627633.

Jain, S.M., 2001. Tissue culture-derived variation in crop improvement. Euphytica, 118, 153-166.

Leitão, S.G., Castro, O., Fonseca, E.N., Julião, L.S., Tavares, E.S., Leo, R.R.T., Vieira, R.C., Oliveira, D.R., Leitão, G.G., Martino, V., Sulsen, V., Barbosa, Y.A.G., Pinheiro, D.P.G., Silva, P.E.A., Teixeira, D.F., Junior, I.N., Lourenço, M.C.S., 2006. Screening of Central and South American plant extracts for antimycobacterial activity by the Alamar Blue test. Revista Brasileira de Farmacognosia, 16, 6-11.

Loureiro, J., Capelo, A., Brito, G., Rodriguez, E., Silva, S., Pinto, G., Santos, C., 2007. Micropropagation of Juniperus phoenicea from adult plant explants and analysis of ploidy stability using flow cytometry. Biologia Plantarum, 51, 7-14.

Marie, D., Brown, S.C., 1993. A cytometric exercise in plant DNA histograms, with $2 \mathrm{C}$ values for 70 species. Biology of the cell, $78,41-51$.

Murashige, T., Skoog, F., 1962. A revised medium for rapid growth and bioassays with tobacco tissue culture. Physiologia Plantarum, 15, 473-497.

Palomino, G., Dolezel, J., Cid, R., Brunnera, I., Méndez, I., Rubluo, A., 1999. Nuclear genome stability of Mammillaria san-angelensis (Cactaceae) regenerants induced by auxins in long-term in vitro culture. Plant Science, 141, 191-200.

Pascual, M.E., Slowing, K., Carretero, E., Mata, D.S., Villara, A., 2001. Lippia: traditional uses, chemistry and pharmacology: a review. Journal of Ethnopharmacology, 76, 201-214.

Peixoto, P.H.P., Salimena, F.R.G., Santos, M.O., Garcia, L.S., Pierre, P.M.O., Viccini, L.F., Otoni, W.C., 2006. In vitro propagation of endangered Lippia filifolia mart. and schauer ex schauer. In Vitro Cellular \& Developmental Biology Plant, 42, 558-561. 
Phillips, R.L., Kaepples, S.M., Olhoft, P., 1994. Genetic instability of plant tissue cultures: breakdown of normal controls. Proceedings of the National Academy of Sciences of the United States of America, 91, 5222-5226.

Salimena, F.R.G., Múlgura, M.E., 2015. Notas taxonômicas em Verbenaceae do Brasil. Rodriguésia, 66, 191-197.

Sousa, S.M., Torres, G.A., Viccini, L.F., 2012. Karyological studies in Brazilian species of Lippia L. (Verbenaceae). Anais da Academia Brasileira de Ciências, 84, 1029-1037.

Troncoso, N.S., 1974. Los Géneros de Verbenáceas de Sudamérica extratropical (Argentina, Chile, Bolivia, Paraguay, Uruguay y Sur de Brasil). Darwiniana, 18, 295-412.
Viccini, L.F., Costa, D.C.S., Machado, M.A., Campos, A.L., 2004. Genetic diversity among nine species of Lippia (Verbenaceae) based on RAPD Markers. Plant Systematics and Evolution, 246, 1-8.

Viccini, L.F., Praça, M.M., Romanel, E., Peixoto, P.H.P., Pierre, P., Souza, D., Sousa, S.M., Salimena, F.R.G., 2005. Chromosome numbers in the genus Lippia (Verbenaceae). Plant Systematics and Evolution, 256, 171-178.

Vieira, R. F., 1999. Conservation of medicinal and aromatic plants in Brazil, in: Janick, J. (Ed.), Perspectives on new crops and new uses. VA: ASHS Press, Alexandria, pp 152-159. 